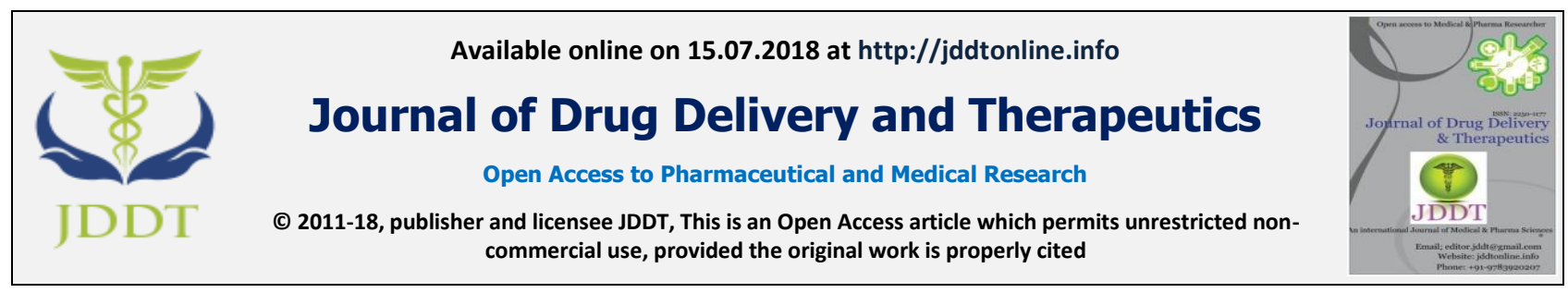

Open $\odot$ Access

Research Article

\title{
LAXATIVE ACTIVITY OF HYDROALCOHOLIC LEAVES EXTRACT OF PUTRANJIVA ROXBURGHII.
}

\author{
Yadav Shivansh*, Kumar Prevesh, Shridhar Bhawna, Shukla Divaker, Baiga Ved Pal, Mani Munesh \\ SPS, IFTM University, Moradabad 244002, U.P. India
}

\section{ABSTRACT}

Background: This study was aimed to assess the possible laxative effect of roxburghii hydroalcoholic leaves extract of Putranjiva in albino's Wistar rats.

Method: Rats were divided in 5 groups of 6 animals each, I group served as control, II group as standard (sodium picosulfate) while group III, IV and V were treated with leaves extract of Putranjiva roxburghii at doses of 250,500 and $750 \mathrm{mg} / \mathrm{kg}$ respectively. The statistical analysis of results were carried out using and one-way analysis (ANOVA) followed by Student t-test.

Result and Discussion: The laxative activity was determined based on the weight of the faeces matter. The effects of the hydroalcoholic leaves extract of Putranjiva roxburghii and reference also evaluated. The hydroalcoholic leaves extract of Putranjiva roxburghii administered orally at three different doses produced significant laxative activity and reduced loperamide induced constipation in dose dependent manner. The effect of the extract at $500 \mathrm{mg} / \mathrm{kg}$ (p.o.) was similar to that of reference drug sodium picosulfate $(5 \mathrm{mg} / \mathrm{kg}$, p.o).

Conclusion: The results showed that hydroalcoholic leaves extract of Putranjiva roxburghii has a significant laxative activity.

Keywords: Laxative, Loperamide, Constipation.

Article Info: Received 10 March, 2018; Review Completed 30 May 2018; Accepted 02 June 2018; Available online 15 July 2018

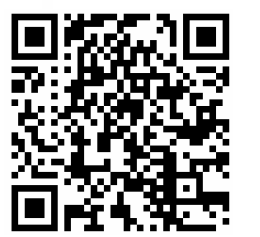

Cite this article as:

Yadav S, Kumar P, Shridhar B, Shukla D, Baiga VP, Mani M, Laxative activity of hydroalcoholic leaves extract of Putranjiva roxburghii., Journal of Drug Delivery and Therapeutics. 2018; 8(4):142-144

DOI: http://dx.doi.org/10.22270/jddt.v8i4.1741

*Address for Correspondence: Shivansh Yadav, SPS, IFTM University, Moradabad - 244002 U.P, India

\section{INTRODUCTION}

Constipation is costiveness refers to movements of bowel that are infrequent and/or hard to pass ${ }^{1}$. Constipation is a symptom with many causes. These causes are obstructed defecation. About $50 \%$ of patients evaluated for constipation at tertiary referral hospitals have obstructed defecation. This type of constipation has mechanical and functional causes. Constipation causes include diet, hormones, adverse effects and toxicity of heavy metals ${ }^{2}$. Laxatives are among the most widely used drugs. However, their consumption is limited due to insufficient efficacy, especially when used regularly or with contraindications. Cardiotoxic and arrhythmogenic effects have been occurred with magnesium purgatives and cisapride ${ }^{3}$. Cramping, diarrhoea, hypercalcemia, hyperphosphatemia and hypokalemia are among the most common side effects ${ }^{4}$. The use of laxatives such as senna compounds and bisacodyl may be associated with colonic neoplasia ${ }^{4-6}$.
The search for novel safe laxative drugs seems, therefore, inevitable. The traditional use of Putranjiva roxburghii in constipation we have evaluated the laxative effect of Putranjiva roxburghii and that provide the scientific ground on the use of laxative.

\section{MATERIAL AND METHODS}

\section{Collection and Extraction of Plant Material:}

The leaves of Putranjiva roxburghii were collected from Lucknow city and authenticated by Department of Botany, IFTM University, Moradabad. A voucher specimen was preserved in the Department for future reference. The dried leaves were powdered mechanically. The powdered material exhaustively extracted with hydroalcoholic solvent for 48 hours. The extract was filtered and concentrated in vacuum under reduced pressure using rotary flash evaporator, dried in the dessicator. The yield was recorded and the extract was kept in refrigerator. 
Animals:

Wistar albino rats, weighing 120-150 g, were used for acute toxicity study and evaluation of pharmacological studies. Animals were housed in standard environmental conditions and fed with standard rodent diet and water.

\section{Acute Oral Toxicity Study and Selection of Doses:}

Acute oral toxicity studies of hydroalcoholic extract was determine as per Orgnization of Economic Co-Operation and Development (OECD) guideline no. 423 (Acute oral toxicity class method). It was observed that the Putranjiva roxburghii is not producing any toxicity up to $2000 \mathrm{mg} / \mathrm{kg}$ dose orally. Hence (250 and 500 and 750 $\mathrm{mg} / \mathrm{kg}$ ) were selected for this study.

\section{Laxative Activity Test:}

Rats fasted for $12 \mathrm{~h}$ before the experiment were placed individually in cages lined with clean filter paper. Rats were divided in five groups with the I group acting as the control and administered saline $(5 \mathrm{ml} / \mathrm{kg}$, p.o.) that acted as the negative control. The II group received sodium picosulfate $(5 \mathrm{mg} / \mathrm{kg}$, p.o.), this served as the positive control. The III, IV and V groups received 250, 500 and $750 \mathrm{mg} / \mathrm{kg}$ per os of the Putranjiva roxburghii hydroalcoholic leaves extract. The administration was done using metal oropharyngeal cannula. The faeces production (total number of normal as well as wet faeces) in all five groups was monitored for $16 \mathrm{~h}^{7}$.

\section{Laxative Activity on Loperamide Induced Constipation in Rats:}

This study was carried out, as earlier described by Takahura et $\mathrm{al}^{8}$. Rats were placed individually in cages lined with clean filter paper, allowed to fast for 18 hours and divided into five groups of six animals each. The I group received normal saline $(5 \mathrm{ml} / \mathrm{kg}, \mathrm{p} . \mathrm{o})$ and served as a negative control. The II group received per os the standard drug sodium picosulfate $(5 \mathrm{mg} / \mathrm{kg})$. The hydroalcoholic leaves extract of Putranjiva roxburghii $(250,500$, and $750 \mathrm{mg} / \mathrm{kg}$, p.o.) was administered per os to the last three groups of rats respectively. After one hour, all the animals received loperamide $(5 \mathrm{mg} / \mathrm{kg}$, p.o.) by gavage. The faeces production (total number of normal as well as wet faeces) in all five groups were monitored for 8 hours.

\section{RESULTS}

\section{Effect of Hydroalcoholic Leaves Extract of Putranjiva roxburghii on Laxative Activity:}

In this study, the different doses of the extract showed dose dependent increase in faecal output of rats when compared to the control group (table 1). There was less significant difference between the extract at the dose of $250 \mathrm{mg} / \mathrm{kg}$ (p.o.) and control group. The effects of hydroalcoholic leaves extract of Putranjiva roxburghii at doses of $500 \mathrm{mg} / \mathrm{kg}$ (p.o.) increased faecal output of rats compared to control group. The effect of the extract at the doses $500 \mathrm{mg} / \mathrm{kg}$ (p.o.) was comparable to that of the standard drug sodium picosulfate $(5 \mathrm{mg} / \mathrm{kg}$, p.o.).

Effect of Hydroalcoholic Leaves Extract of Putranjiva roxburghii on Loperamide Induced Constipation in Rats:

In the loperamide-induced constipation, the hydroalcoholic leaves extract of Putranjiva roxburghii at the doses of 500 and $750 \mathrm{mg} / \mathrm{kg}$ (p.o.), increased the total number of faeces in a dose dependent manner, and the results were statistically significant (Table 2). There was less significant effect with the dose of $250 \mathrm{mg} / \mathrm{kg}$ (p.o.) of the extract compared with control. The reduction of the loperamide induced constipation at 500 $\mathrm{mg} / \mathrm{kg}$ (p.o.) of plant extract treatment was found to be almost comparable with that of treatment by $5 \mathrm{mg} / \mathrm{kg}$ of sodium picosulfate.

Table 1: Laxative Activity of Hydroalcoholic Extract of Putranjiva roxburghii in Rats

\begin{tabular}{|c|c|c|c|}
\hline \multirow{2}{*}{$\begin{array}{c}\text { Group } \\
\text { (Treatment) }\end{array}$} & Dose $(\mathbf{m g} / \mathbf{k g})$ & \multicolumn{2}{|c|}{ Faeces output (g) } \\
\cline { 3 - 4 } & & $\mathbf{0} \mathbf{- 8 ~ h r}$ & $\mathbf{8}-\mathbf{1 6} \mathbf{~ h r}$ \\
\hline Control (Saline) & $5 \mathrm{ml} / \mathrm{kg}$ & $0.8270 \pm 0.0006831$ & $0.8437 \pm 0.008732$ \\
\hline Sodium picosulfate & $5 \mathrm{mg} / \mathrm{kg}$ & $4.856 \pm 0.01438^{* * *}$ & $4.733 \pm 0.03135^{* * *}$ \\
\hline Putranjiva roxburghii & $250 \mathrm{mg} / \mathrm{kg}$ & $3.162 \pm 0.01621^{* * *}$ & $3.443 \pm 0.1667 * * *$ \\
\hline Putranjiva roxburghii & $500 \mathrm{mg} / \mathrm{kg}$ & $4.205 \pm 0.01713^{* * *}$ & $4.538 \pm 0.1079 * * *$ \\
\hline Putranjiva roxburghii & $750 \mathrm{mg} / \mathrm{kg}$ & $3.808 \pm 0.004475^{* * *}$ & $3.862 \pm 0.03940^{* * *}$ \\
\hline
\end{tabular}

Values are expressed as mean \pm S.E.M $(\mathrm{n}=6) ; * * * \mathrm{p}<0.001$ compared to control group.

Table 2: Effect of Putranjiva roxburghii Hydroalcoholic Extract on Loperamide Induced Constipation in Rats

\begin{tabular}{|c|c|c|}
\hline $\begin{array}{c}\text { Group } \\
\text { (Treatment) }\end{array}$ & Dose $\mathbf{~ m g} / \mathbf{k g}$ & Weight of faeces (g) \\
\cline { 2 - 3 } & & $\mathbf{0}-\mathbf{8 ~ h r}$ \\
\hline Control (Saline) & $5 \mathrm{ml} / \mathrm{kg}$ & $0.9085 \pm 0.003243$ \\
\hline Sodium picosulfate & $5 \mathrm{mg} / \mathrm{kg}$ & $3.076 \pm 0.03930^{* * *}$ \\
\hline Putranjiva roxburghii & $250 \mathrm{mg} / \mathrm{kg}$ & $1.917 \pm 0.003433^{*} * *$ \\
\hline Putranjiva roxburghii & $500 \mathrm{mg} / \mathrm{kg}$ & $3.081 \pm 0.01488^{* * *}$ \\
\hline Putranjiva roxburghii & $750 \mathrm{mg} / \mathrm{kg}$ & $2.219 \pm 0.1403 * * *$ \\
\hline
\end{tabular}

Values are expressed as mean \pm S.E.M $(\mathrm{n}=6)$; $* * * \mathrm{p}<0.001$ compared to control group. 


\section{Statistical Analysis:}

Data obtained are presented as means \pm standard error of mean (S.E.M.) for the number of animals in each group $(n=6)$. The differences between the data obtained from 'test' animal groups and the data obtained from untreated animal groups, were subjected to one-way analysis of variance (ANOVA; 99.99\% confidence interval), followed by Dunnett's test. Values with $\mathrm{p}<$ 0.001 compared with the control group were considered as being significantly different.

\section{DISCUSSION}

The laxative activity of Putranjiva roxburghii was studied in rats. The results showed that an oral administration of the hydroalcoholic leaves extract of Putranjiva roxburghii produced significant and dose dependant increase in faeces output of rats. These effects were comparable with that of sodium picosafate (standard drug) at moderate dose of $500 \mathrm{mg} / \mathrm{kg}$. Sodium picosulfate affects electrolyte transport and smooth muscle contractility in the intestine. Its cathartic action is due to water accumulation in the intestine ${ }^{9}$. Sodium picosulfate is a member of the polyphenolic group of stimulant laxatives. Following oral administration, it is converted in the colon to an active form through the action of bacterial enzymes ${ }^{10}$. As a result, its effects are directed the colon, where it stimulates peristalsis and, in common with other laxatives, reduces water reabsorption leading to the softening of faeces. The observed activities therefore suggest that laxative activity of hydroalcoholic leaves extract of Putranjiva roxburghii may be mediated through this mechanism of action of Sodium picosulfate. Adverse effects associated with use of sodium picosafate are intestinal blockage, appendicitis, abdominal pain or cramping, nausea, bloating, vomiting, inflamed bowels or fecal impaction etc. that can be overcome possibly by replacing it with Putranjiva roxburghii for treatment of constipation ${ }^{11-12}$.

\section{CONCLUSION}

This study showed that hydroalcoholic leaves extract of Putranjiva roxburghii has laxative effects in addition to the various physiological effects. Further studies may be directed at characterizing the bioactive ingredients that are responsible for the observed activity in the plant.

\section{ACKNOWLEDGEMENTS}

The author wish to thank Dr. Sushil Kumar, Director, SPS, IFTM University, Moradabad for encouragement throughout the period of this research work. I would also like to give special thanks to my guide Dr. Munesh Mani for his inspiration \& providing necessary facilities to carry out this research work.

\section{REFERENCES}

1. Chatoor D, Emmnauel "A Constipation and evacuation disorders". Best Pract Res Clin Gastroenterol 2009; 23 (4): 517-30.

2. Andromanakos, N.; Skandalakis, P.; Troupis, T.; Filippou, D. "Constipation of anorectal outlet obstruction: Pathophysiology, evaluation and management". Journal of Gastroenterology and Hepatology 2006; 21 (4): 638.

3. Harris LA. Current mechanisms of action in treatment of chronic constipation and irritable bowel syndrome; Adv Stud Med 2006; 6:S237-S242.

4. Washabau RJ. Gastrointestinal motility disorders and gastrointestinal prokinetic therapy. Vet Clin North Amer. Small Anim Pract 2003; 33:1007-1028.

5. Qureshi T, Melonakos TK. Acute hypermagnesemia after laxative use. Ann Emerg Med 1996; 28:552-555.

6. Xing JH, Soffer EE. Adverse effects of laxatives. Dis Colon Rectum 2001; 44:12011209.

7. Capasso F, Mascolo N, Autore G, Romano V: Laxatives and the production of autacoids by rat colon. J pharm Pharmacol 1986; 38:627-629.
8. Takaharu S, Fujie M, Yuji L, Kouji M, Hideo K: Laxative and Antidiarrhoeal activity of polycarbophil in mice and rats. Jpn J Pharmacol 2002; 89:133-141.

9. Chitme HR, Chandra R, Kaushik S: Studies on Antidiarrhoeal activity on calotropis gigantean in experimental animals. J Pharm Pharmaceut Sci 2004; 7:7075 .

10. Ganapaty S., Dash G. K., Subburaju T. and Suresh P., Diuretic, laxative and toxicity studies of Cocculus hirsutus aerial parts, Fitoterapia 2002; 73: 28- 31.

11. Fjällskog ML, Frii L, Bergh J. Paclitaxel-induced cytotoxicity the effects of cremophor EL on two human breast cancer cell lines with acquired multidrug resistant phenotype and induced expression of the permeability glycoprotein. Eur J Cancer. 1994; 30A:687-690.

12. Longanga-Otshudi A, Vercruysse A, Foriers A: Contribution to the ethnobotanical, phytochemical and pharmacological studies of traditionally used medicinal plants in the treatment of dysentery and diarrhoea in Lomela area, Democratic Republic of Congo (DRC). J Ethnopharmacol 2000; 71:411423. 